\title{
Rational placement of grain production - the basis for ensuring food security
}

\author{
Guzaliya Klychova $^{1}$, Alsou Zakirova ${ }^{1, *}$, Ilnur Safiullin ${ }^{1}$, Zufar Zakirov $^{1}$, Shaukat \\ Khusainov $^{2}$ and Galina Zakharova ${ }^{1}$ \\ ${ }^{1}$ Kazan State Agrarian University, 65, Karl Marx, 420015 Kazan, Russia \\ ${ }^{2}$ Russian State Agrarian University - Moscow Timiryazev Agricultural Academy, 47, \\ Timiryazevskaya, 127550, Moscow, Russia
}

\begin{abstract}
The most important prerequisite for achieving the main goal of the country's agro-industrial complex - ensuring its food security and efficient agricultural production - is the optimal location of its individual industries and production facilities by territorial units. The urgency of increasing the efficiency of agricultural production in general, and grain production in particular, has increased with Russia's accession to the World Trade Organization. The purpose of the study is to develop scientifically grounded proposals and practical recommendations to improve the efficiency of grain production location in the Republic of Tatarstan. The study's objectives: to reveal the economic essence of agricultural production location taking into account the main principles and influence of the main factors; to assess the current state of grain crop production location in the region; to develop the directions of grain production development at macroand micro-economic levels. Abstractological, statistical-economic, calculation and balance methods of research were used in the work. In the article the criteria and indexes of level and efficiency of production placement are offered; the condition and tendencies of development of grain crops placement are analyzed; methodical approaches and project decisions on perfection of grain crops placement on the regional level are grounded. The practical significance of the obtained research results lies in the fact that the developed measures contribute to the substantiation of optimal parameters of grain crop production location in the Republic of Tatarstan in the context of its natural and economic zones and municipal administrative districts.
\end{abstract}

\section{Introduction}

Theoretical basis for agricultural production location is the social division of labour. The development of the social division of labor is the basis for the transition of agriculture to the industrial path with its characteristic rhythmic and flow, intersectoral cooperation, integration of enterprises, the formation of economic relations and interaction of sub-projects of market relations.

\footnotetext{
*Corresponding author: zakirovaar@mail.ru
} 
Agricultural location is a spatial distribution of production of various types of products and industries within the country, its economic areas, zones, administrative areas and specific enterprises.

If before the 1990s in Russia the placement of the main types of agricultural products was carried out by bringing the planned government procurement, now, unfortunately, agricultural producers do not have a guaranteed market for their products. At the same time, it should be noted that the form of government procurement and redistribution of the pure product, which existed under the command and administrative system, is completely unacceptable under market conditions. Moreover, even under the planning and distribution system economic conditions of production were not fully taken into account, agricultural producers were "detached" from the results of their work and could not creatively manage. Under market conditions, a scientifically grounded location of production suggests, first of all, the intensification of entrepreneurial activity and freedom of action $[1,2]$.

At the same time, in our opinion, when solving the issues of improving the location of agricultural production and its separate branches, the state should play its important role.

While locating any production, it is necessary to follow certain principles and take into account the main factors that determine the development of agricultural production [3, 4].

The main principles of agricultural production location are as follows:

- approximation of production to sources of raw materials and areas of product consumption [5];

- location of production of this or that product, first of all, in those areas where the cost of socially necessary labor for its receipt and transportation is the lowest and continuous growth of gross output is ensured [6-8];

- improvement of the ecological situation [9-12];

- creation of effective system of personnel management [13].

- detailed account of natural conditions; establishment of correct proportions not only between agriculture and industry, but also between separate branches of agricultural production [14];

- account of market conjuncture; the fullest use of production potential of agrarian sector $[15,16]$

- ensuring economic and food security of the country $[17,18]$;

- realization of advantages and use of economic benefits of the international division of labor.

In our opinion, the following principles should be observed first of all when placing production of certain types of products, in particular grain:

- estimation of market capacity and approaching of production to suburban zones and large industrial centers, where the greatest demand for the products of the industry is observed [19-21];

- detailed account of soil and climatic conditions of production for the purpose of maximization of output from a unit of land at decrease in the prime cost of production of a unit of production [22];

- the most complete use of the existing production capacities of agricultural formations, based on the availability and condition of the applied technologies, the system of machines, qualified workers [23];

- ensuring timely accounting, control and reporting of all performed production operations $[24,25]$.

When assessing the rationality of placement it should be taken into account that no single criterion can characterize the efficiency of agricultural production sufficiently. Therefore, when assessing the efficiency it is reasonable to apply a system of indicators, which can be divided into the following groups: 
1) generalizing - indicators of gross and marketable product cost, gross income and profit per unit of land area, per unit of live labor cost, per 1 rub. fixed assets and production costs, level of profitability of realized production, profit norm;

2) private - the yield of agricultural crops, animal productivity, labor intensity, production and commercial costs, implementation price, the level of production (in kind) on 100 hectares of the corresponding land area and others.

To assess the rationality of placement of specific types of agricultural products, we suggest using a simplified method associated with the calculation of the total score by the following formula:

$$
\mathrm{C}=\mathrm{a} \times \mathrm{I}_{\mathrm{y}}+\mathrm{b} \times \mathrm{I}_{\mathrm{o}}+\mathrm{c} \times \mathrm{I}_{\mathrm{t}},
$$

where $\mathrm{C}$ is the combined benefit of the accommodation conditions;

$\mathrm{I}_{\mathrm{y}}$ - animal yield or productivity index, expressed as a ratio of the specified indicators by a district or an agricultural enterprise to the regional or district average respectively;

$\mathrm{I}_{\mathrm{o}}$ - cost recovery index, expressed as a ratio of receipts per 1 ruble cost recovery index expressed as a ratio of revenues per 1 ruble of commercial cost of sales by a district or an agricultural enterprise to the regional or regional average, respectively;

$I_{t}$ - labor intensity index, expressed as a ratio of labor intensity of production at the average regional or enterprise level to the regional or district level, respectively;

a, b, c - coefficients characterizing the degree of influence of the corresponding element on the generalizing index determined by solving the problem of multiple correlation.

In order to obtain a generalized comprehensive assessment of agricultural production location it is necessary to take into account the existing differentiation of business conditions of agrarian enterprises, which is reflected in the value of their production (resource) potential. The use of generalized assessment of the efficiency of placement, based on the definition of production (resource) potential and efficiency of its use in specific agricultural enterprises allows, on the one hand, to determine the quantitative characteristics of the influence of factor signs on the performance indicators, and on the other hand - to identify the reserves available to improve the efficiency of agricultural production based on the current economic conditions, including through improving its placement [26-29].

\section{Materials and Methods}

The Republic of Tatarstan is located in the eastern part of the Eastern European Plain, at the confluence of the Volga and Kama rivers, is part of the Volga Federal District of the Russian Federation, the administrative center is Kazan.

The population of the Republic as of January 1, 2020 was 3902.6 thousand people, including 912.0 thousand people in rural areas. The average annual number of employees in all sectors of the economy over the past five years is about 1.8 million people.

The climate is temperate continental, with warm summers and moderately cold winters. The average annual temperature ranges from +2.2 to +3.2 degrees, falling from south-west to north-east. Average annual rainfall in the country ranges from $430-500 \mathrm{~mm}$ with an average annual evaporation of 550-570 $\mathrm{mm}$. Two thirds of precipitation falls on summer and autumn. Adverse aspects of the climate include uneven distribution of snow on the territory in winter, autumn-spring frosts, droughts and dry weather.

The country's soils are very diverse. Almost one third of the territory (about 32\%) is occupied by chernozems, grey, dark grey forest and weakly podzolic soils account for $38 \%$, and sod-podzolic soils account for $17 \%$ of the area of Tatarstan. Due to the high plowing of land, the forest area in Tatarstan is small $-16.4 \%$. The share of agricultural land in the total land fund of Tatarstan is $67.3 \%$. 
The existing relatively favorable natural, climatic and economic conditions determine the important role of the Republic of Tatarstan in Russia's agricultural production and in ensuring its economic and food security. In the territorial division of labor in agriculture of the Russian Federation and the Volga Federal District its place is determined by a number of basic products, among which the production of grain, sugar beet, milk, meat and potatoes is the most important.

The Republic of Tatarstan has a large territory with diverse natural conditions and resources. It is in homogeneously inhabited and developed, that is why it is possible to single out within the Republic natural and economic areas characterized by certain specialization of farms of the territory and its specific location.

As of the beginning of 2020, 6 natural and economic zones have been established within the country:

1. The Kazan suburban includes the Arsk, Atna, Verkhneuslon, Vysokogorsk, Zelenodolsk, Laishevsk and Pestrechinsk districts;

2. The Nizhnekamsk suburban includes the districts of Agryz, Aktanysh, Elabuga, Zainsk, Mendeleev, Menzelin, Muslumov, Nizhnekamsk, Sarmanovsk and Tukaev;

3. The South-Eastern includes the Aznakaevo, Almetyevsk, Bavlinsk, Bugulma, Leninogorsk and Yutaza districts;

4. Zakamskaya includes Aksubaevsky, Alekseevsky, Alkeevsky, Novosheshma, Nurlatsky, Spassky, Cheremshansky and Chistopolsky districts;

5. Predkamskaya includes Baltasinsky, Kukmorsky, Mamadyshsky, Rybno-Slobodsky, Sabinsky and Tyulyachinsky districts;

6. The Predvolzhskaya Region includes Apastovsky, Buinsky, Drozhzhanovsky, Kaybitsky, Kamsko-Ustiinsky and Tetyushsky districts.

Table 1. Natural and climatic conditions of natural and economic zones of the Republic of Tatarstan.

\begin{tabular}{|l|c|c|c|c|c|c|}
\hline \multirow{2}{*}{ Indicators } & \multicolumn{6}{c|}{ Natural and economic zones ${ }^{\mathbf{1}}$} \\
\cline { 2 - 8 } & $\mathbf{1}$ & $\mathbf{2}$ & $\mathbf{3}$ & $\mathbf{4}$ & $\mathbf{5}$ & $\mathbf{6}$ \\
\hline 1.Total land fund, thousand ha & 1047.6 & 1627.9 & 997.1 & 1407.0 & 918.1 & 745.4 \\
\hline $\begin{array}{l}\text { 2.The area of agricultural land, } \\
\text { thousand ha }\end{array}$ & 704.9 & 1057.9 & 680.4 & 943.2 & 603.9 & 576.0 \\
\hline $\begin{array}{l}\text { 3. Share of agricultural land in total } \\
\text { land fund, \% }\end{array}$ & 67.3 & 65.0 & 68.2 & 67.0 & 65.8 & 77.3 \\
\hline 4. Plowing of agricultural land, \% & 75.7 & 75.4 & 69.5 & 81.3 & 75.1 & 78.5 \\
\hline 5. Territory forestry, \% & 14.8 & 14.2 & 20.2 & 17.7 & 20.5 & 9.9 \\
\hline 6.Average annual temperature, C & 2.6 & 2.6 & 2.2 & 2.8 & 2.5 & 3.0 \\
\hline 7. Average annual rainfall, mm & 457 & 444 & 451 & 426 & 449 & 479 \\
\hline $\begin{array}{l}\text { 8. Score on the economic valuation of } \\
\text { agricultural land }\end{array}$ & 24.69 & 28.28 & 28.05 & 31.51 & 24.00 & 30.37 \\
\hline $\begin{array}{l}\text { 9. Density of rural population, } \\
\text { people/sq.km }\end{array}$ & 19.6 & 12.2 & 11.4 & 12.4 & 18.6 & 16.4 \\
\hline
\end{tabular}

11 - Kazan suburban, 2 - Nizhnekamsk suburban, 3 - South-Eastern, 4 - Zakamskaya, 5 -

Predkamskaya, 6 - Predvolzhskaya.

As can be seen from Table 1, natural and economic zones differ not only in their size, but also in the nature of land fund use. For example, in suburban zones the share of agricultural lands is considerably lower in comparison with others, and in particular with the Predvolzhskaya zone due to the fact that in the first large land areas are allocated to the lands of cities, industry, energy, etc., they contain the largest industrial hubs (e.g. KazanZelenodolsky, Nizhnekamsk territorial production complex), the main scientific, technical and cultural potential is concentrated there, as it is much higher than the special institutions and those employed in these sectors per capita. 
There is a great differentiation of land productivity in the Republic: from 24.00 in the Predkamskaya region to 31.51 points (i.e. by $31 \%$ ) in the Zakamskaya natural and economic zone, which to a certain extent affects the intensity of production, location of agricultural sectors and specialization of agricultural enterprises.

Grain production has been and remains the basis for the development of all agricultural production in Russia. More than 35\% of the area of arable land and more than half of the total sown area are allocated for grain crops. The share of grain and leguminous crops in the total volume of gross agricultural output in all categories of farms is about $15 \%$, and in agricultural organizations - more than $30 \%$.

Quantitative characteristics of agriculture location are indicators of specific weight of separate agricultural zones or economic areas in the gross output of corresponding types of products in the country as a whole or in any region. As noted earlier, the Republic of Tatarstan has 6 natural and economic zones, each of which is characterized by more favorable conditions for the production of this or that product. However, there is no explicit location for grain production in the Republic (Table 2).

Table 2. Placement of grain crop production in farms of all categories by natural and economic zones of Republic of Tatarstan for 2011-2018, in \%.

\begin{tabular}{|l|c|c|c|c|c|c|c|c|}
\hline \multirow{2}{*}{\begin{tabular}{c} 
Natural and economic \\
\multicolumn{1}{c|}{\begin{tabular}{c} 
areas \\
\cline { 2 - 10 }
\end{tabular}}
\end{tabular}} & $\mathbf{2 0 1 1}$ & $\mathbf{2 0 1 2}$ & $\mathbf{2 0 1 3}$ & $\mathbf{2 0 1 4}$ & $\mathbf{2 0 1 5}$ & $\mathbf{2 0 1 6}$ & $\mathbf{2 0 1 7}$ & $\mathbf{2 0 1 8}$ \\
\hline Kazan suburban & 13.6 & 13.1 & 12.6 & 12.6 & 14.5 & 12.9 & 12.0 & 13.1 \\
\hline Nizhnekamsk suburban & 24.9 & 28.3 & 22.1 & 25.5 & 25.3 & 25.4 & 25.9 & 26.2 \\
\hline South-Eastern & 11.4 & 12.4 & 15.8 & 13.5 & 12.5 & 12.4 & 12.5 & 11.1 \\
\hline Zakamskaya & 23.0 & 19.3 & 23.4 & 19.2 & 20.0 & 22.2 & 21.8 & 22.2 \\
\hline Predkamskaya & 13.7 & 12.1 & 10.7 & 15.3 & 14.2 & 13.3 & 12.8 & 13.8 \\
\hline Predvolzhskaya & 13.3 & 14.9 & 15.3 & 13.9 & 13.5 & 13.9 & 15.1 & 13.6 \\
\hline
\end{tabular}

The indicators presented in Table 2 show that the Nizhnekamsk suburban and Zakamskaya natural and economic zones account for the largest share of the total grain production in the Republic of Tatarstan. Whereas, in the dynamics there is a tendency to increase the share of agricultural formations of Nizhnekamsk suburban, Prekamskaya, Predvolzhskaya, and the share of Kazan suburban, Zakamskaya and South-Eastern natural and economic zones of the region.

The main factors determining the share of territorial units in the production of this or that product are the areas under crops (Table 3) and the yields achieved (Table 4).

Table 3. Sown areas of grain crops in farms of all categories by natural and economic zones of

Republic of Tatarstan for 2011-2018, thousand ha.

\begin{tabular}{|l|c|c|c|c|c|c|c|c|}
\hline \multirow{2}{*}{$\begin{array}{c}\text { Natural and economic } \\
\text { areas }\end{array}$} & \multicolumn{9013}{|c|}{ Years } \\
\cline { 2 - 10 } & $\mathbf{2 0 1 1}$ & $\mathbf{2 0 1 2}$ & $\mathbf{2 0 1 3}$ & $\mathbf{2 0 1 4}$ & $\mathbf{2 0 1 5}$ & $\mathbf{2 0 1 6}$ & $\mathbf{2 0 1 7}$ & $\mathbf{2 0 1 8}$ \\
\hline Kazan suburban & 226.9 & 210.1 & 212.2 & 199.4 & 202.5 & 203.0 & 196.7 & 187.8 \\
\hline Nizhnekamsk suburban & 379.2 & 377.5 & 384.7 & 381.8 & 384.1 & 379.1 & 373.1 & 360.0 \\
\hline South-Eastern & 219.4 & 206.5 & 230.5 & 241.8 & 235.0 & 238.9 & 222.0 & 201.1 \\
\hline Zakamskaya & 391.4 & 352.7 & 372.8 & 335.2 & 354.0 & 353.6 & 332.0 & 326.1 \\
\hline Predkamskaya & 232.0 & 208.9 & 197.3 & 198.8 & 197.1 & 196.7 & 188.0 & 195.1 \\
\hline Predvolzhskaya & 204.0 & 199.2 & 215.9 & 215.2 & 222.4 & 216.2 & 218.6 & 213.9 \\
\hline Republick of Tatarstan & 1652.9 & 1554.9 & 1613.4 & 1572.3 & 1595.1 & 1587.4 & 1530.4 & $\begin{array}{c}1484, \\
0\end{array}$ \\
\hline
\end{tabular}


During the analyzed period the areas sown under grain crops in the Republic of Tatarstan decreased by 168.9 thousand hectares or by $10.2 \%$. The greatest reduc-tion of sowing areas was observed in Kazan suburban natural and economic zone, where the reduction of sowing areas for grain crops was 39.1 thousand ha or $17.2 \%$, Zakamskaya - 65.3 thousand ha or $16.7 \%$ and Predkamskaya - 36.9 thou-sand ha or $15.9 \%$, and in Nizhnekamsk suburban and South-Eastern - a slight re-duction (5.1 and 8.3\%, respectively). At the same time, in the Predvolzhskaya natu-ral and economic zone there is an increase in grain sown areas - by 9.9 thousand ha or $4.9 \%$.

Table 4. Grain crop yields in farms of all categories by natural and economic zones of Republic of Tatarstan for 2011-2018, centner from 1 ha.

\begin{tabular}{|l|c|c|c|c|c|c|c|c|}
\hline \multirow{2}{*}{$\begin{array}{c}\text { Natural and } \\
\text { economic areas }\end{array}$} & \multicolumn{7}{|c|}{ Years } \\
\cline { 2 - 9 } & $\mathbf{2 0 1 1}$ & $\mathbf{2 0 1 2}$ & $\mathbf{2 0 1 3}$ & $\mathbf{2 0 1 4}$ & $\mathbf{2 0 1 5}$ & $\mathbf{2 0 1 6}$ & $\mathbf{2 0 1 7}$ & $\mathbf{2 0 1 8}$ \\
\hline Kazan suburban & 29.2 & 18.6 & 15.5 & 21.3 & 24.2 & 26.0 & 29.7 & 25.4 \\
\hline $\begin{array}{l}\text { Nizhnekamsk } \\
\text { suburban }\end{array}$ & 32.0 & 22.4 & 15.0 & 22.5 & 22.2 & 27.5 & 33.7 & 26.7 \\
\hline South-Eastern & 25.3 & 17.9 & 17.9 & 18.8 & 17.9 & 21.3 & 27.3 & 20.2 \\
\hline Zakamskaya & 28.7 & 16.3 & 16.4 & 19.3 & 19.1 & 25.8 & 32.0 & 24.9 \\
\hline Predkamskaya & 28.7 & 17.3 & 14.2 & 25.9 & 24.2 & 27.8 & 33.1 & 25.9 \\
\hline Predvolzhskaya & 31.8 & 22.4 & 18.5 & 21.8 & 20.4 & 26.3 & 33.6 & 23.3 \\
\hline $\begin{array}{l}\text { Republic of } \\
\text { Tatarstan }\end{array}$ & 29.4 & 19.2 & 16.2 & 21.4 & 21.1 & 25.9 & 31.8 & 24.6 \\
\hline
\end{tabular}

Over 2011-2018, grain crop yields in farms of all categories in the Republic of Tatarstan fluctuated significantly: from $16.2 \mathrm{~kg}$ from 1 ha in 2013 to $31.8 \mathrm{~kg}$ from 1 ha in 2017 . At the same time, it should be noted that in all natural and economic zones of the Republic yield indicators for 2017 exceed their values for the base period, but by the reporting year 2018 there was a decline in yield.

\section{Results}

According to the conducted researches, the most significant indicators of economic efficiency of agrarian sector of economy functioning at the present stage of its development are the cost price of grain crops (table 5) and profitability of production (table 6).

Table 5. The cost price of 1 centner grain crops in agricultural organizations by natural and economic zones of Republic of Tatarstan for 2011-2018, rub.

\begin{tabular}{|l|c|c|c|c|c|c|c|c|}
\hline \multirow{2}{*}{\begin{tabular}{c}
\multirow{2}{*}{$\begin{array}{c}\text { Natural and } \\
\text { economic } \\
\text { areas }\end{array}$} \\
\cline { 2 - 10 }
\end{tabular}} & $\mathbf{2 0 1 1}$ & $\mathbf{2 0 1 2}$ & $\mathbf{2 0 1 3}$ & $\mathbf{2 0 1 4}$ & $\mathbf{2 0 1 5}$ & $\mathbf{2 0 1 6}$ & $\mathbf{2 0 1 7}$ & $\mathbf{2 0 1 8}$ \\
\hline Kazan suburban & 420 & 481 & 519 & 557 & 612 & 617 & 577 & 623 \\
\hline Nizhnekamsk suburban & 375 & 514 & 559 & 598 & 732 & 679 & 593 & 732 \\
\hline South-Eastern & 389 & 488 & 546 & 543 & 663 & 728 & 606 & 610 \\
\hline Zakamskaya & 414 & 531 & 600 & 639 & 784 & 720 & 586 & 587 \\
\hline Predkamskaya & 412 & 472 & 590 & 509 & 582 & 590 & 525 & 591 \\
\hline Predvolzhskaya & 378 & 474 & 570 & 583 & 698 & 650 & 489 & 654 \\
\hline Republic of Tatarstan & 388 & 489 & 567 & 586 & 687 & 679 & 577 & 649 \\
\hline
\end{tabular}


Until 2015, the Republic of Tatarstan had a clear trend of increasing production costs per 1 hectare of grain crops, which was due, on the one hand, to an increase in the level of costs per 1 hectare of crops and, on the other hand, a decrease or rather low level of grain crop yields; in the next two years, a decrease in production costs was due to an increase in yields - by 10.7 tonnes from 1 hectare or more than half, and a significant increase by the reporting year - a decrease in yields by 7.2 tonnes from 1 hectare.

It should be noted that during the analyzed period the level of prime cost of grain crops in the Republic of Tatarstan increased by 261 rubles or more than 2/3, while in Nizhnekamsk suburban natural and economic zone - by 357 rubles or almost twice, in Zakamskaya - by 173 rubles or $41.8 \%$, in Predkamskaya - by 179 rubles or $43.7 \%$. In the reporting year agricultural formations of Zakamskaya and Predkamskaya zones reached the lowest grain cost levels - 587 and 591 rubles, respectively.

Table 6. Profitability level from grain sales in agricultural organizations by natural and economic zones of Republic of Tatarstan for 2011-2018, \%.

\begin{tabular}{|l|c|c|c|c|c|c|c|c|}
\hline \multirow{2}{*}{$\begin{array}{c}\text { Natural and } \\
\text { economic } \\
\text { areas }\end{array}$} & \multicolumn{7}{|c|}{ Years } \\
\cline { 2 - 9 } & $\mathbf{2 0 1 1}$ & $\mathbf{2 0 1 2}$ & $\mathbf{2 0 1 3}$ & $\mathbf{2 0 1 4}$ & $\mathbf{2 0 1 5}$ & $\mathbf{2 0 1 6}$ & $\mathbf{2 0 1 7}$ & $\mathbf{2 0 1 8}$ \\
\hline Kazan suburban & 9.8 & 9.5 & 26.0 & 9.9 & 17.2 & 22.1 & 10.2 & 25.2 \\
\hline Nizhnekamsk suburban & 7.7 & 7.5 & 16.8 & 5.8 & 9.1 & 19.3 & 3.3 & 6.0 \\
\hline South-Eastern & 4.8 & 7.9 & 12.8 & 5.7 & 16.3 & 12.0 & -2.6 & 6.7 \\
\hline Zakamskaya & 9.5 & 3.4 & 7.2 & 8.9 & 5.9 & 12.6 & 13.0 & 24.6 \\
\hline Prekamskaya & 3.9 & 5.1 & 12.5 & 15.2 & 22.8 & 29.3 & 24.3 & 22.2 \\
\hline Predvolzhskaya & 12.1 & 20.2 & 19.9 & 15.3 & 19.8 & 21.4 & 15.8 & 31.3 \\
\hline Republic of Tatarstan & 9.6 & 11.2 & 16.4 & 9.9 & 14.6 & 17.2 & 8.7 & 11.9 \\
\hline
\end{tabular}

Table 6 shows that the highest profitability in grain production of the Republic was in 2016, and the lowest - in 2017 due to a sharp decline in average selling prices (from 796 to 627 rubles per 1 centner). For the whole period under research only in agricultural organizations of the Predvolzhskaya natural and economic zone there is a higher level of profitability from grain crops sales. At the same time for 2015-2018 stable profitability (more than 20\%) is achieved in agricultural organizations of the Predvolzhskaya natural-economic zone.

We believe that when assessing the efficiency of production location, it is advisable to apply the aggregate favorability index (Table 7,8):

$$
I=\frac{I_{\mathrm{y}} \cdot I_{\mathrm{o}}}{I_{c}},
$$

where $I_{y}$ - is the yield index, expressed as a ratio of the specified indicators for a district or an agricultural enterprise to the regional or district average, respectively;

$\mathrm{I}_{0}$ - cost recovery index expressed as a ratio of revenues per 1 rub. of commercial cost of sales by a district or an agricultural enterprise to the regional or regional average, respectively;

$I_{c}$ - cost recovery index expressed as a ratio of unit cost of production in an average district or enterprise to the regional or regional average, respectively.

The calculations show that the most favorable areas for the location of grain crop production are: Aktanysh, Apastov, Arsky, Atninsky, Baltasinsky, Buinsky, Zelenodolsky, Kaybitsky, Mamadysh, Tetyush, Yutazinsky districts; the least favorable ones are in Ak- 
subayevsky, Almetyevsk, Leninogorsky, Mendeleevsky, Nizhnekamsk, Cheremshansky districts.

The analysis of Table 8 shows that in the future to increase the production of grain crops in the Republic of Tatarstan it is necessary to grow more in the agricultural formations of Kazan suburban, Predkamskaya and Predvolzhskaya natural and economic zones, and for the farms of Nizhnekamsk suburban, South-Eastern and Zakamskaya should develop adequate measures, first of all, aimed at the fullest use of the production potential of enterprises of the agricultural sector.

At substantiation of directions and ways of realization of factors of increase of efficiency it is necessary to proceed from the fact, that the decision of a problem of improvement of agricultural production placing demands application of the effective economic mechanism based on a combination of the state regulation and self-regulation, stimulation of rural commodity producers and protectionism. Measures to improve the efficiency of production placement should be implemented at two levels - macro- and microeconomic.

Table 7. Aggregate favorability index in agricultural organizations by administrative regions on the average for 2011-2018.

\begin{tabular}{|l|c|c|c|c|}
\hline Administrative Region & $\mathbf{I}_{\mathbf{y}}$ & $\mathbf{I}_{\mathbf{0}}$ & $\mathbf{I}_{\mathbf{c}}$ & $\mathbf{I}$ \\
\hline Agryzsky & 0.851 & 0.964 & 0.957 & 0.857 \\
\hline Aznakaevsky & 1.052 & 0.907 & 1.108 & 0.862 \\
\hline Aksubaevsky & 0.847 & 0.933 & 1.058 & 0.747 \\
\hline Aktanyshski & 1.254 & 1.079 & 0.937 & 1.445 \\
\hline Alekseevsky & 1.007 & 1.044 & 1.111 & 0.946 \\
\hline Alkeevsky & 1.088 & 1.011 & 1.159 & 0.948 \\
\hline Almetyevsk & 0.807 & 0.801 & 1.217 & 0.531 \\
\hline Apastovski & 1.113 & 1.066 & 0.908 & 1.306 \\
\hline Arsky & 1.109 & 1.081 & 0.889 & 1.349 \\
\hline Atnian & 1.291 & 1.015 & 0.924 & 1.418 \\
\hline Bavlinsky & 0.934 & 0.980 & 0.889 & 1.029 \\
\hline Baltasinsky & 1.308 & 1.073 & 0.924 & 1.519 \\
\hline Bugulminsky & 0.688 & 0.903 & 0.965 & 0.643 \\
\hline Buinsky & 1.120 & 1.094 & 0.998 & 1.227 \\
\hline Verhneuslonsky & 0.832 & 0.997 & 1.083 & 0.766 \\
\hline Vysokogorsky & 1.024 & 0.898 & 0.995 & 0.924 \\
\hline Drozhzhanovsky & 0.972 & 0.956 & 1.061 & 0.876 \\
\hline Elabuzhsky & 0.921 & 0.985 & 0.981 & 0.925 \\
\hline Zainsky & 1.215 & 0.981 & 1.044 & 1.143 \\
\hline Zelenodolsky & 1.089 & 1.211 & 0.970 & 1.359 \\
\hline Kaybitsky & 1.021 & 1.094 & 0.930 & 1.200 \\
\hline Kamsko-Ustiinsky & 0.789 & 1.045 & 0.961 & 0.858 \\
\hline Kukmorsky & 1.024 & 1.007 & 0.920 & 1.120 \\
\hline Laishevsky & 0.918 & 1.013 & 0.915 & 1.017 \\
\hline Leninogorsky & 0.854 & 0.872 & 1.009 & 0.738 \\
\hline Mamadyshski & 0.979 & 1.081 & 0.878 & 1.204 \\
\hline Mendeleevsky & 0.747 & 0.935 & 0.982 & 0.711 \\
\hline Menzelinsky & 1.087 & 0.982 & 0.908 & 1.175 \\
\hline Muslumovsky & 0.946 & 0.943 & 1.019 & 0.875 \\
\hline Nizhnekamsk & 0.981 & 0.732 & 1.304 & 0.551 \\
\hline Novoshesminsky & 0.969 & 1.088 & 0.886 & 1.190 \\
\hline Nurlatsky & 1.121 & 0.976 & 1.049 & 1.043 \\
\hline & & & & \\
\hline
\end{tabular}




\begin{tabular}{|l|l|l|l|l|}
\hline Pestrechinsky & 0.861 & 1.018 & 0.956 & 0.917 \\
\hline Rybno-Slobodsky & 0.986 & 1.046 & 0.962 & 1.072 \\
\hline Sabinsky & 1.168 & 0.998 & 0.984 & 1.184 \\
\hline Sarmanovsky & 1.133 & 1.032 & 1.015 & 1.152 \\
\hline Spassky & 0.949 & 1.035 & 1.009 & 0.973 \\
\hline Tetyuszsky & 1.071 & 1.124 & 0.972 & 1.238 \\
\hline Tukaevsky & 1.143 & 1.098 & 1.164 & 1.078 \\
\hline Tyulyachinsky & 0.990 & 1.035 & 0.934 & 1.096 \\
\hline Cheremshansky & 0.747 & 0.829 & 1.124 & 0.551 \\
\hline Chistopol & 0.892 & 0.963 & 1.030 & 0.834 \\
\hline Yutazinsky & 0.994 & 1.295 & 0.749 & 1.717 \\
\hline
\end{tabular}

Table 8. Aggregate index of favorability in agricultural organizations by natural and economic zones of Republic of Tatarstan on average for 2011-2018.

\begin{tabular}{|l|c|c|c|c|}
\hline $\begin{array}{c}\text { Natural and economic } \\
\text { areas }\end{array}$ & $\boldsymbol{I}_{\boldsymbol{y}}$ & $\boldsymbol{I}_{\boldsymbol{o}}$ & $\boldsymbol{I}_{\boldsymbol{c}}$ & $\boldsymbol{I}$ \\
\hline Kazan suburban & 1.018 & 1.033 & 0.962 & 1.107 \\
\hline Nizhnekamsk suburban & 1.028 & 0.973 & 1.031 & 0.991 \\
\hline South-Eastern & 0.888 & 0.960 & 0.990 & 0.920 \\
\hline Zakamskaya & 0.952 & 0.985 & 1.053 & 0.904 \\
\hline Predkamskaya & 1.076 & 1.040 & 0.934 & 1.199 \\
\hline Predvolzhskaya & 1.014 & 1.063 & 0.972 & 1.118 \\
\hline
\end{tabular}

At the macroeconomic level in order to create favorable economic conditions for the effective functioning of enterprises in the agricultural sector, including the optimal solution of issues related to the location of production at the present time, the following measures are particularly important:

- providing rural producers with guaranteed sales of some of their products in the face of unfavourable market conditions through the restoration of the system of state order for products, commodity and procurement interventions and state collateral operations;

- restoration and activation of investment processes by reducing the level of aggregate tax burden on commodity producers and its greater differentiation, preservation of the intellectual potential of the industry through increased investment in agricultural science, education and retraining of personnel for the agro-industrial complex [29];

- formation and functioning of the market of scientific and technical production, aimed at development and optimization of normative-legal support of innovation activity in agrarian sphere, improvement of competitive system of selection of projects and programs, development of infrastructure of innovation processes;

- improvement of the system of taxation of agricultural producers, based on the practice of accelerated depreciation, postponement of tax payment and full exemption from it for a certain period of time for small and newly established enterprises;

- application of state guaranteed prices, setting limit prices and tariffs (prices of upper limit) for material and technical resources and services for rural areas, use of protective (threshold) prices for setting fixed customs duties, etc.

Improving the efficiency of agricultural production can be achieved through the formation and functioning of a market for scientific and technical products and the development of innovation activities. The main directions of the state innovation policy should become the main directions:

- the development and improvement of the legal and regulatory framework for innovation activity and its incentive mechanisms; 
- improvement of competitive system of selection of innovative projects and programs;

- realization of technologies and priority directions, which are able to transform the agrarian sector of economy and agricultural areas of the country and separate regions for the better [30, 31];

- development of the innovation process infrastructure, system of information support, expertise, certification and promotion of developments, system of training and retraining of personnel $[32,33]$.

Agricultural production requires such monetary credit, which is accompanied by a relatively high level of government support. In a system of concessional lending, control over the targeted use of resources should be tightened, while the state should not take responsibility for the borrower.

An important form of credit is commodity credit. At the same time, this form of credit should not allow its artificial priority over monetary credit. A subsidiary function of commodity credit should be the guaranteed sale by agricultural producers of those products in the markets where there is insufficient activity of commercial organizations. At present, state commodity crediting is of crucial importance due to the absence, in most cases, of the possibility for commodity producers to choose sales channels, underdeveloped market infrastructure, etc.

A certain place in the regulatory system should be occupied by state collateral operations, which can be carried out at the expense of budget funds, budget loans, as well as under the scheme of concessional lending. Here, agricultural products are the object of collateral with conditions set by the state. For carrying out of more effective pledge operations it is expedient to issue special securities - mortgages which in case of refusal of the mortgagor from mortgaged agricultural production, can address in the market or be redeemed by the state. Application of these operations for agricultural commodity producers is attractive by the fact that they are provided with the possibility of timely receipt of money and facilitation of sale of products at poor market conditions.

The mechanism of state leasing operations needs significant improvement, as in its current form it stimulates the monopoly of intermediaries supplying resources and manufacturers, which, on the one hand, reduces the quality parameters of means of production, and on the other hand, causes the growth of prices for them .To eliminate these shortcomings, it is necessary to select leasing intermediaries on a competitive basis, and the interests of rural producers should be at the forefront, so that leasing meets their real needs for appropriate means of mechanization and automation, the necessary range of products and appropriate quality.

Special attention should be paid to the price relations in agriculture. The main directions of their improvement at the present stage are to solve the following tasks:

- ensuring an optimal combination of market self-regulation of prices and their state regulation;

- control over prices of monopolist enterprises by antimonopoly measures;

- consideration of foreign experience in pricing, use of price support for agricultural producers and price regulation;

- development of the system of contractual relations and coordination at all levels;

- taking into account the specifics of pricing for agricultural products and the main pricing factors: production and sales costs, sales channels, personal income levels, etc.

To maintain equivalence of intersectoral exchange and regulation of its proportions, it is necessary to establish limit prices and tariffs (prices of the upper limit) for material and technical resources and services for rural areas.

At present, it is advisable to apply protective (threshold) prices, which are calculated on the basis of average implementation prices of certain types of products within the country and serve as a basis for determining fixed customs duties and variable customs duties. 
Meeting these challenges at the macroeconomic level will ha ve a positive impact on all aspects of agricultural production, including the rationality of its location. At the same time, at any state of these macroeconomic factors to ensure high efficiency, the issues of agricultural production should be justified at all levels of agricultural management: local, regional and national. It is particularly important to properly address the issues of agricultural production location at the regional level.

At the same time, the main principles of state support should be: targeting, transparency and clarity of mechanisms for its implementation for agricultural producers.

At the microeconomic level, as the results of the conducted researches have shown, the increase of efficiency of the production placement contributes first of all:

- rational intra-farm placement of agricultural crops, buildings and facilities for primary processing, processing and storage of products;

- the most efficient use of the existing production potential of agricultural enterprises;

- the choice of the most acceptable in the current conditions and effective organizational and legal forms of management;

- a strict regime of economy at all stages of final product output;

- selection of the most effective channels for product sales, taking into account the results of market research on market conditions;

- rationalization of labor processes organization in agriculture;

- increasing the efficiency of methods of material and moral stimulation of workers in agriculture and others.

The decision of questions of effective placing of branches of agriculture should be based on identification of intra-regional natural and economic zones, administrative areas and the separate enterprises where manufacture of this or that kind of production is most rational and there are the most favorable conditions for growth of volumes of their manufacture at the least expenses of labour and means. Thus, it is necessary to solve a problem of a combination of interests of society, the enterprises and separate workers, being based on economic management methods. For this purpose, when substantiating the development prospects of agricultural enterprises and territories should be based on objective factors - the resource potential that each enterprise or any administrative and territorial formation has, and the effectiveness of its use in them.

When developing the project of placement of marketable products in agricultural enterprises in the regions of Tatarstan as a criterion indicator of maximum yield was used, the value of which for specific products was determined by the following formula:

$$
\Sigma \mathrm{Q}_{\mathrm{j}}=\Sigma \mathrm{STP}_{\mathrm{i}} \times \mathrm{C}_{\mathrm{ij}} \times\left(\mathrm{I}_{\mathrm{ij}} / \mathrm{I}_{\mathrm{i}}{ }_{\mathrm{i}}\right) / \mathrm{C}_{\mathrm{j}}
$$

where, $\Sigma \mathrm{Q}_{\mathrm{j}}$ is the volume of $\mathrm{j}$-th kind of commodity products in the Republic for the future, centner;

$\mathrm{STP}_{\mathrm{i}}$ - the cost of marketable products in the future in the i-th district, rub.;

$\mathrm{C}_{\mathrm{ij}}$ - coefficient characterizing the specific weight of $\mathrm{j}$-th type of products in the structure of marketable products in the i-th district;

$I_{i j}$ - index of output $j$-th type of marketable product per 1 ha or per 1 head in the $i$-th district, determined through the ratio of the average district to the national average;

$\mathrm{I}^{1}{ }_{\mathrm{i}}$ - average size of indices for all types of marketable products in the $\mathrm{i}$-th district $\left(\mathrm{I}^{1}{ }_{\mathrm{i}}=\Sigma \mathrm{I}_{\mathrm{ij}}\right.$ $\times \mathrm{C}_{\mathrm{ij}}$;

$\mathrm{C}_{\mathrm{J}}$ - comparable price of 1 centner $\mathrm{j}$-type of products, rub.

In general, it should be noted that the administrative regions of the republic have both different levels of resource potential and efficiency of its use. For this reason, they should be considered first of all when determining project indicators and decisions.

The following conditions should serve as a basis for forecasting indicators, which are calculated for the medium term: 
a) the need to increase gross and commercial grains to better meet the needs of the industry;

b) resource potential of each region of the Republic and efficiency of its use;

c) possibilities of growth of resource potential and, as a consequence, volumes of manufactured and sold products, based on its dynamics in each of the regions.

At definition of the design size of resource potential it is expedient to use the reception of alignment of a dynamic series by means of which its size and a standard deviation have been defined. Then with application of the received parameters the forecast of level of potential possibilities on prospect is given, and by means of efficiency of its use volumes of total and commodity output on each administrative area in calculation on unit of the area on prospect are defined.

At the decision of questions on rational placing of concrete kinds of commodity output on farms within the limits of administrative areas it is offered to use the technique based on the account of potential resource possibilities of the agricultural enterprises, factors of specific weight of separate kinds of commodity output in their total volumes and differences in level of its cost price on the enterprises. At the same time, indicators of volumes of placement of specific types of marketable products are determined by the following formula:

$$
\Sigma \mathrm{Q}_{\mathrm{j}}=\Sigma \Sigma \mathrm{OPP}_{\mathrm{i}} \times \mathrm{C}_{\mathrm{ij}} \times \mathrm{k}_{\mathrm{ij}} / \mathrm{C}_{\mathrm{j}}
$$

where $\Sigma Q_{\mathrm{j}}$ is the volume of $\mathrm{j}$-marketable products in the area for the future, centner;

$\Sigma \mathrm{OPP}_{\mathrm{i}}$ - total estimate of resource potential for marketable products in i-type enterprise, rub;

$\mathrm{C}_{\mathrm{ij}}$ - the coefficient characterizing the specific weight of the $\mathrm{j}$ - type of products in the structure of marketable products in the $i$-th enterprise of the district;

$\mathrm{k}_{\mathrm{ij}}$ - efficiency factor, expressed as a ratio of average district cost of $\mathrm{j}$-type to its level in the $\mathrm{i}$-th enterprise.

Achievement of a high level of performance indicators should be based on a system of technical, technological, organizational-economic and other measures to improve the efficiency of economic activity. Maximum effect is achieved in case of their complex application. Of particular importance in the system of these measures are the following:

- introduction of scientifically grounded systems of agriculture, which provide for the deepening of specialization of intra-farm divisions;

- a strict regime of economy at all stages of final production;

- rationalization of the organization of labor processes in agricultural sectors;

- strengthening the role of the main branches by increasing their marketability, concentration and intensification of production;

- assistance in raising the professional level of specialists and employees of agricultural enterprises, retraining and requalification of personnel in accordance with market requirements;

- participation in horizontal and vertical cooperation and integration;

- conducting marketing research and using its results in practice, etc.

Among these and other measures, well organized market research is particularly important for agricultural enterprises. The role of marketing research is significantly increasing due to the loss of guaranteed sales channels for its products by rural producers in the transition to market forms of management. At the same time, the sale of products to commercial intermediaries is not widespread enough due to underdeveloped market infrastructure, insufficient volume of intermediary and sales services, special transport, modern storage facilities, etc. 


\section{Discussion}

When designing the location of crop production, the complex of natural and economic conditions of management should be taken into account. To assess the natural and climatic conditions of cultivation of agricultural crops, including cereals, it is advisable to use the methodology of determining the bioclimatic potential (BCP) of specific territories. According to territorial units of the Republic of Tatarstan, BCP on cultivation of grain crops practically does not differ, at the same time agrotechnical terms of performance of the main operations of technological process in the branch are slightly different.

Table 9. Crop sowing areas allocation forecast for farms of all categories by administrative regions of the Republic of Tatarstan.

\begin{tabular}{|c|c|c|c|c|}
\hline \multirow{2}{*}{ Administrative district } & \multirow{2}{*}{$\begin{array}{c}\text { In fact }(2018 \\
\text { year })\end{array}$} & \multirow{2}{*}{$\begin{array}{c}\text { At. } \\
\text { future prospect }\end{array}$} & \multicolumn{2}{|c|}{ Rejection } \\
\hline & & &,+- & in \% \\
\hline Agryzsky & 22481 & 22481 & - & - \\
\hline Aznakaevsky & 43576 & 43576 & - & - \\
\hline Aksubaevsky & 36288 & 36288 & - & - \\
\hline Aktanyshski & 47878 & 57454 & 9576 & 20,0 \\
\hline Alekseevsky & 50861 & 50861 & - & - \\
\hline Alkeevsky & 36114 & 36114 & - & - \\
\hline Almetyevsk & 44010 & 44010 & - & - \\
\hline Apastovski & 33598 & 40318 & 6720 & 20,0 \\
\hline Arsky & 52808 & 63370 & 10562 & 20,0 \\
\hline Atnian & 18211 & 21853 & 3642 & 20,0 \\
\hline Bavlinsky & 28331 & 29181 & 850 & 3,0 \\
\hline Baltasinsky & 31393 & 37672 & 6279 & 20,0 \\
\hline Bugulminsky & 36273 & 36273 & - & - \\
\hline Buinsky & 55164 & 66197 & 11033 & 20,0 \\
\hline Verhneuslonsky & 16938 & 16938 & - & - \\
\hline Vysokogorsky & 31519 & 31519 & - & - \\
\hline Drozhzhanovsky & 36363 & 36363 & - & - \\
\hline Elabuzhsky & 31608 & 31608 & - & - \\
\hline Zainsky & 36929 & 42468 & 5539 & 15,0 \\
\hline Zelenodolsky & 14010 & 16812 & 2802 & 20,0 \\
\hline Kaybitsky & 26745 & 32094 & 5349 & 20,0 \\
\hline Kamsko-Ustiinsky & 16800 & 16800 & - & - \\
\hline Kukmorsky & 31304 & 32869 & 1565 & 5,0 \\
\hline Laishevsky & 22135 & 22135 & - & - \\
\hline Leninogorsky & 32067 & 32067 & - & - \\
\hline Mamadyshski & 38252 & 42077 & 3825 & 10,0 \\
\hline Mendeleevsky & 12568 & 12568 & - & - \\
\hline Menzelinsky & 49017 & 53919 & 4902 & 10,0 \\
\hline Muslumovsky & 50422 & 50422 & - & - \\
\hline Nizhnekamsk & 20092 & 20092 & - & - \\
\hline Novoshesminsky & 44787 & 47474 & 2687 & 6,0 \\
\hline Nurlatskya & 33965 & 34644 & 679 & 2,0 \\
\hline Pestrechinsky & 32182 & 32182 & - & - \\
\hline Rybno-Slobodsky & 46053 & 47895 & 1842 & 4,0 \\
\hline Sabinsky & 25632 & 28195 & 2563 & 10,0 \\
\hline Sarmanovsky & 46022 & 52925 & 6903 & 15,0 \\
\hline
\end{tabular}




\begin{tabular}{|c|c|c|c|c|}
\hline Spassky & 41003 & 41003 & - & - \\
\hline Tetyuszsky & 45261 & 52050 & 6789 & 15,0 \\
\hline Tukaevsky & 42954 & 45531 & 2577 & 6,0 \\
\hline Tyulyachinsky & 22489 & 23838 & 1349 & 6,0 \\
\hline Cheremshansky & 29894 & 29894 & - & - \\
\hline Chistopol & 53138 & 53138 & - & - \\
\hline Yutazinsky & 16865 & 20238 & 3373 & 20,0 \\
\hline
\end{tabular}

Among economic conditions, when producing grain, first of all, it is necessary to take into account the development of production infrastructure and special equipment (grain harvesters, primary grain cleaning machines, grain dryers, etc.), seasonal labor force. In order to increase the production of grain crops in agricultural organizations of the Republic of Tatarstan, we propose to take full advantage of inter-farm cooperation. It is necessary to cultivate different types and varieties of grain crops in terms of vegetation period, which makes it more rational to use the available equipment.

Taking into account the above mentioned conditions and favorable location of grain crops, a medium-term forecast of placement of areas sown by administrative regions of the Republic was given (Table 9).

As can be seen from Table 9, it is planned to increase the areas under crops and legumes in agricultural formations in 22 out of 43 administrative districts of the republic, and to leave the rest at the level of 2018. The largest increase of sowing areas, based on favorable location, is planned in Buinskiy (by 11033 ha), Arsk (by 10562 ha), Aktanysh (by 9576 ha) districts.

In terms of natural and economic zones, the placement of areas sown with grain crops in farms of all categories of the Republic of Tatarstan will be as follows (Table 10).

Table 10. Forecast of grain crop sowing areas placement in farms of all categories by natural and economic zones of the Republic of Tatarstan, ha.

\begin{tabular}{|l|c|c|c|c|}
\hline \multirow{2}{*}{$\begin{array}{c}\text { Natural and } \\
\text { economic areas }\end{array}$} & \multirow{2}{*}{$\begin{array}{c}\text { In fact (2018 } \\
\text { year) }\end{array}$} & \multirow{2}{*}{ For the future. } & \multicolumn{2}{|c|}{ Rejection } \\
\cline { 4 - 5 } Kazan suburban & 187803 & 204809 & 17006 & 8.6 \\
\hline $\begin{array}{l}\text { Nizhnekamsk } \\
\text { suburban }\end{array}$ & 359971 & 389468 & 29497 & 7.9 \\
\hline South-Eastern & 201122 & 205345 & 4223 & 1.9 \\
\hline Zakamskaya & 326050 & 329417 & 3367 & 1.0 \\
\hline Predkamskaya & 195123 & 212547 & 17424 & 9.3 \\
\hline Predvolzhskaya & 213931 & 243822 & 29891 & 13.7 \\
\hline $\begin{array}{l}\text { Republic of } \\
\text { Tatarstan }\end{array}$ & 1484000 & 1585407 & 101407 & 6.6 \\
\hline
\end{tabular}

As a result of implementation of our proposed measures, the areas under crops may increase by more than 100 thousand hectares or 6.6\% from the level of 2018 in the whole country. At the same time in 4 out of 6 natural and economic zones of the region: Predvolzhskaya, Predkamskaya, Kazanskaya suburban and Nizhnekamskaya suburban, the growth rates are envisaged to be higher, and in the South-Eastern and Zakamskaya zones $1.9 \%$ and $1.0 \%$ respectively. As a result of the proposed measures, the share in the total structure of crops in the Predvolzhskaya zone will increase by 0.6 percentage points - from $14.4 \%$ to $15.4 \%$. Prospective crop production volumes in farms of all categories by natural and economic zones of the Republic of Tatarstan are presented in table 11. 
Table 11. Prospective crop production volumes in farms of all categories by natural and economic zones of the Republic of Tatarstan, thousands of tons.

\begin{tabular}{|l|c|c|c|c|}
\hline \multirow{2}{*}{$\begin{array}{c}\text { Natural and } \\
\text { economic areas }\end{array}$} & \multirow{2}{*}{$\begin{array}{c}\text { In fact (2018 } \\
\text { year) }\end{array}$} & \multirow{2}{*}{ For the future } & \multicolumn{2}{|c|}{ Rejection } \\
\cline { 4 - 5 } & 477.4 & 520.7 & 43.2 & in \% \\
\hline Kazan suburban & 959.9 & 1038.6 & 78.7 & 8.2 \\
\hline $\begin{array}{l}\text { Nizhnekamsk } \\
\text { suburban }\end{array}$ & 406.4 & 415.0 & 8.5 & 2.1 \\
\hline South-Eastern & 811.2 & 819.5 & 8.4 & 1.0 \\
\hline Zakamskaya & 504.8 & 549.9 & 45.1 & 8.9 \\
\hline Predkamskaya & 497.8 & 567.4 & 69.6 & 14.0 \\
\hline Predvolzhskaya & 3657.6 & 3911.0 & 253,4 & 6.9 \\
\hline $\begin{array}{l}\text { Republic of } \\
\text { Tatarstan }\end{array}$ & & &
\end{tabular}

Due to optimization of grain crop sowing areas placement and the most complete use of the natural factor, opportunities of inter-farm cooperation and available technical means of the industry in the future it is planned to increase the volumes of gross harvest of crops by 253 thousand tons or almost by $7 \%$ from the level of 2018 .

Defined in the above way perspective parameters of production volumes placement by regions can serve as a generalized assessment of their production capacities and a general guideline for establishing rational specialization. At the same time at substantiation of structure of manufacture in concrete agricultural enterprises it is necessary to reveal and establish rational sizes of their branches. It can be carried out both on the basis of study of mass data on results of activity of farms, and by means of economic and mathematical modeling of rational parameters of their industrial and branch structures.

\section{Conclusions}

Thus, in today's environment there are increased demands on the quality of economic decisions in all spheres of the economy, and especially in agriculture. In this regard, the problem of optimal location of agricultural production becomes extremely important as a factor in increasing efficiency.

The placement of production in agriculture as a form of social division of labor has been widely studied in theory. At the same time, in spite of solid theoretical bases, its practical solution at the present stage of agricultural development is in unsatisfactory condition. Moreover, as shown by the results of studies, the issues of rational placement of agricultural production in the last 20-25 years have not been given due attention neither in agrarian and economic science, nor in economic practice.

At substantiation of directions and ways of realization of factors of increase of efficiency it is necessary to proceed from that the decision of a problem of improvement of placing of agricultural production demands application of the effective economic mechanism based on a combination of state regulation and self-regulation, stimulation of rural commodity producers and protectionism. Measures to improve the efficiency of production placement should be implemented at two levels - macro- and microeconomic.

Optimization of agricultural placement should be based on the theory of efficiency of public production and optimal functioning of economic systems with limited resource supply and be based on the corresponding criterion of optimality. As a criterion of optimality of placement of agricultural production at the macro level it is necessary to use the maximum satisfaction of solvent demand of the population for high quality foodstuffs and the necessary range of products at affordable prices, at the micro level - profit maximization. 


\section{References}

1. J. Gaffney, J. Bing, P.F. Byrne, K.G. Cassman, D. Warner, Global Food Security 23, 236-244 (2019) doi: 10.1016/j.gfs.2019.08.003

2. M.M. Wei, F. Zhang, Computers \& Operations Research 93, 166-176 (2018) doi: 10.1016/j.cor.2017.12.005

3. J.D. Michler, World Development 129, 104888 (2020) doi: 10.1016/j.worlddev.2020.104888

4. A. Klychova, G. Klychova, A. Zakirova, R. Sungatullina, K. Mukhamedzyanov, E. Philippova, E3S Web of Conferences 110, 02072 (2019) doi: 10.1051/e3sconf/201911002072

5. J. Sadeghi, A. Dehnokhalaji, Computers \& Industrial Engineering 127, 344-352 (2019) doi: 10.1016/j.cie.2018.10.011

6. H. Poffenbarger, G. Artz, G. Dahlke, W. Edwards, M. Hanna, J. Russell, H. Sellers, M. Liebman, Agricultural Systems 157, 51-69 (2017) doi: 10.1016/j.agsy.2017.07.001

7. S. Huttunen, Journal of Rural Studies 71, 36-45 (2019) doi: 10.1016/j.jrurstud.2019.09.004

8. G.S. Klychova, B.G. Ziganshin, A.R. Zakirova, G.R. Valieva, A.S. Klychova, Journal of Engineering and Applied Sciences 12, 4958-4965 (2017) doi: 10.3923/jeasci.2017.4958.4965

9. E.J. Marr, P. Howley, Journal of Rural Studies 68, 100-111 (2019) doi: 10.1016/j.jrurstud.2019.01.013

10. A. Dhar, M.A Naeth, P.D. Jennings, M.G. El-Din, Science of The Total Environment 20, 134602 (2019) doi: 10.1016/j.scitotenv.2019.134602

11. Zh. Qin, M. Storozum, H. Liu, X. Zhang, T.R. Kidder, Quaternary International 521, 2534 (2019) doi: 10.1016/j.quaint.2019.06.033

12. A. Grzelak, M. Guth, A. Matuszczak, B. Czyżewski, A. Brelik, Journal of Cleaner Production 241, 118304 (2019) doi: 10.1016/j.jclepro.2019.118304

13. A.K. Subaeva, M.M. Nizamutdinov, L.M. Mavlieva, M.N. Kalimullin, BIO Web of Conferences 17, 00226 (2020) doi: 10.1051/bioconf/20201700226

14. M. Li, J. Li, V.P. Singh, Q. Fu, D. Liu, G. Yang, Geoderma 353, 55-69 (2019) doi: 10.1016/j.geoderma.2019.06.023

15. S. Wenzel, R. Paulen, B. Beisheim, S. Krämer, S. Engell, IFAC-PapersOnLine 50, 12446-12451 (2017) doi: 10.1016/j.ifacol.2017.08.1919

16. A. Mehrpouya, M.-L. Salles-Djelic, Accounting, Organizations and Society 76, 12-31 (2019) doi: 10.1016/j.aos.2019.01.003

17. G. Klychova, A. Zakirova, A. Dyatlova, A. Klychova, E. Zaugarova, N. Zalyalova, E3S Web of Conferences 135, 04008 (2019) doi: 10.1051/e3sconf/201913504008

18. E. Grigoreva, L. Garifova, Procedia Economics and Finance 24, 266-273 (2015) doi: 10.1016/S2212-5671(15)00658-9

19. G. Klychova, A. Zakirova, Sh. Khusainov, A. Dyatlova, U. Raheem, E. Sagadeeva, E3S Web of Conferences 157, 04022 (2020) doi: 10.1051/e3sconf/202015704022

20. A.A. Hatab, M.E.R. Cavinato, A. Lindemer, C.-J. Lagerkvist, Cities 94, 129-142 (2019) doi: 10.1016/j.cities.2019.06.001

21. M. Li, Q. Fu, V.P. Singh, D. Liu, X. Gong, Agricultural Water Management 233, 106105 (2020) doi: 10.1016/j.agwat.2020.106105 
22. Th. Nguyen-Huy, R.C. Deo, Sh. Mushtaq, J. Kath, Sh. Khan, Weather and Climate Extremes 21, 76-89 (2018) doi: 10.1016/j.wace.2018.07.002

23. A.K. Subaeva, M.M. Nizamutdinov, L.M. Mavlieva, BIO Web of Conferences 17, 00178 (2020) doi: 10.1051/bioconf/20201700178

24. G. Klychova, A. Zakirova, E. Sadrieva, F. Avkhadiev, A. Klychova, E3S Web of Conferences 91, 06002 (2019) doi: 10.1051/e3sconf/20199106002

25. G.S. Klychova, A.R. Zakirova, K.Z. Mukhamedzyanov, E.R. Sadrieva, A.S. Klychova, Journal of Engineering and Applied Sciences 12(19), 4966-4973 (2017) doi: 10.3923/jeasci.2017.4966.4973

26. V. Alary, M. Corbeels, F. Affholder, S. Alvarez, A. Soria, J.H. Valadares Xavier, F.A.M. da Silva, E. Scopel, Agricultural Systems 144, 33-45 (2016) doi: 10.1016/j.agsy.2016.01.008

27. P.S. Maya Gopal, R. Bhargavi, Computers and Electronics in Agriculture 165, 104968 (2019) doi: 10.1016/j.compag.2019.104968

28. A.J. DeVincentis, S.S. Solis, E.M. Bruno, A. Leavitt, D. Zaccaria, Journal of Environmental Management 261, 110205 (2020) doi: 10.1016/j.jenvman.2020.110205

29. G. Klychova, A. Zakirova, R. Mannapova, K. Pinina, Y. Ryazanova, E3S Web of Conferences 110, 02075 (2019). doi: 10.1051/e3sconf/201911002075

30. T.-G. Katalin, T. Rahoveanu, M. Magdalena, T. István, Procedia Economics and Finance 8, 729-736 (2014) doi: 10.1016/S2212-5671(14)00151-8

31. D.J. Pannell, R.S. Llewellyn, M. Corbeels, Agriculture, Ecosystems \& Environment 187, 52-64 (2014) doi: 10.1016/j.agee.2013.10.014

32. M.P. Costa, J.C. Schoeneboom, S.A. Oliveira, R.S. Viñas, G.A. de Medeiros, Journal of Cleaner Production 171, 1460-1471 (2018). doi: 10.1016/j.jclepro.2017.10.063

33. R.B. Flavell, Global Food Security 12, 15-21 (2017) doi: 10.1016/j.gfs.2016.10.001 